\title{
Challenges of Mogadishu Local Government Revenue
}

\author{
Abdullahi Ali Mohamed ${ }^{1, a,}$ \\ ${ }^{1}$ School of Humanities and Social Science, Department of Public Administration, \\ Beihang University, Beijing China No,37 Xueyuan Rd, 100191,
}

abiidcaddecali114@gmail.com

Keywords: Local Government, Revenue, Tax, Decentralization.

\begin{abstract}
Local government that has power to self-finance promotes socioeconomic development and it creates an environments where local communities have access to get basic services and it also enhances the responsiveness of government to the citizens. There have been efforts of local government to finance itself but the struggle ended up expenditures exceeded than revenues and it was a time that the central government has not capacity to transfer funds to fill the balance gaps; the solution was reduction of local government spending (low salary/lack of salary of municipal servants) and decline of basic service deliveries.

This paper examines the key current sources of financing local governments as well as the existing source of finance that were not being utilized yet due to prevailing challenges.

The study explores the exercise and mechanisms of taxing system, revenues collection strategies, weak or lack of fiscal decentralization and incompetent collection enforcement. Somalia has not yet create up to date data base of taxable sources such as commercial, residential, and agricultural sectors and its difficult for the local government to promote self- financing strategies unless to remove barriers of classic by placing more sophisticated collection of revenue as well as creating new sources of finance.
\end{abstract}

\section{Introduction}

Local authority refers to administrative bodies that are officially mandated to handle all public services within specific geographical areas for example, cities, municipalities, towns, boards, and counties. Local authorities are responsible for the provision of public services to the locals through funds' utilization generated from the local residents, and in addition to grants and loans from the central government (Chernick \& Reschovsky, 2006). To ensure local authorities execute their functions effectively, a wide, but secure and buoyant financial base is very critical (Bird \& Slack, 1993). The local authorities should also be in possession of liberal modicum to be in a better position to alter composition and level of their sources of revenue in regard to fiscal decentralization logic. According to Fox \& Gurley (2006), Fiscal decentralization helps devolve spending powers and taxing from the central government authorities, especially at the sub-national levels.

Fiscal decentralization entails sources of revenue, levels of expenditure, and tax rates determination, and according to Kubler \& Rochat (2010), most of the local government system of collection strives to achieve certain goals namely; safeguard the cash from the government, accelerate available funds' receipts, and keeping a minimum of banking costs. The collection systems within the local authority vary depending on the size within the jurisdiction, the nature of received revenues, and the acceptable payment methods (Magala \& Rubagumya, 2005). The revenues' core sources can therefore be classified into internal and external; however, over-reliance of the external sources elevates the central government's dominance on the local authority, which in turn reduces them to a mere authority without finances.

\section{Challenges of Local Government Revenue}

Mogadishu local government is no exception to challenges that face local governments. Since local governments are assigned the role of paying for the goods and services to its residents within a specified geographical area, these residents are therefore required to pay for them (Weeks et al., 2009). These local governments experience numerous challenges, which most of them are related to revenue collection among others. Since Somalia has not, until today, created an up to date database system of collecting revenues of taxable sources for example, agricultural and commercial sectors, it is therefore a challenge for Mogadishu local government to facilitate smooth financing strategies (Myers \& Dietz, 2002). It is unless the local government places a more advanced revenue collection system, while it aims at creating new financial sources. 
Currently, the Mogadishu local government struggles with its Revenue because of poor methods of revenue collection and infringed sources of Revenue. The main source of local government finances comes from the national government of Somalia. With numerous challenges that are experienced in Mogadishu, there are minimal income generating projects put in place, however; other sources include intergovernmental transfers (ITGs) is one of the main facets of financing.

Collection of property tax does not exist since mobile assets census is not fixed; neither does maintenance of proper register to avail information of the exact value of property within the capital. With the current revenue collection system put in place, Mogadishu local government experience challenges to its revenues collection strategies, taxing system mechanism, and weak fiscal decentralization (Thirsk, 1987). These challenges have since resulted to the following amount of revenues from its current revenues source, which makes it difficult to facilitate most of its activities.

Table 1. Current sources of Revenues of Mogadishu Local Government

\begin{tabular}{|c|c|c|}
\hline Sources of Revenues & $\mathbf{2 0 1 3}$ & $\mathbf{2 0 1 4}$ \\
\hline Markets & $212,291.65$ & $401,553.05$ \\
\hline Other (livestock, Bajaj, Checkpoints, Khat, \\
mines) & $1,127,976.86$ & $1,980,700.27$ \\
\hline Business license & $378,977.50$ & $431,286.00$ \\
\hline Fines and forfeitures & & \\
\hline Public registration & 886.00 & $224,871.00$ \\
\hline Registration of NGO and Companies & $48,966.00$ & $59,500.00$ \\
\hline Land and building permits & $970,779.35$ & $1,015,304.50$ \\
\hline Plate No. and driving license & $55,026.70$ & $87,083.50$ \\
\hline Intergovernmental transfers & $7,487,366.41$ & $8,750,382.41$ \\
\hline Conditional grants & & \\
\hline Total Revenue & $\mathbf{1 0 , 2 8 2 , 2 7 0 . 4 7}$ & $\mathbf{1 2 , 9 5 0 , 6 8 0 . 5 8}$ \\
\hline
\end{tabular}

Source: Mogadishu local government archive

\section{Main Challenges of Revenue}

Security: Security is the main challenge to Mogadishu local government's revenue collection because of lack of enough finances to reach certain places. Considering the local government is seen to have enough ability in collection of taxes across the capital, security problem have led to most of the officials killed (Sano \& Alfredsson, 2002). Security concerns have also led to some of the officials from the revenue collection department to avoid some areas that has abundant of resources.

Mogadishu local government has not been spared either. With attacks and killings inside the capital, it has since become difficult for the local government to conduct its revenues collection activities (Parker, 2010). Additionally, with numerous business premises attacked, fear has rock the entire capital prompting the residents to shun their business activities for fear of their lives. All this have contributed to minimal revenues collection as a result of lack of proper systems and security challenges.

Lack of community awareness: Somalia is one of the few countries with lack of community awareness on tax payment. Majority of the people also do not like paying because the countries' history never advocated for the importance of paying taxes (Mulindabingwi \& Singer, 2005). Somalia, until recently, had an unstable government with inexistence of non- sophisticated government systems to cub tax aversion by its citizens. Currently, tax payment awareness is taking its toll on the local government since most of the capital's activities are not executed well due to lack of adequate funds.

Additionally, there is also limited awareness on the importance of tax collection. The locals in Mogadishu fear for their contribution to the local government citing corruption and minimal evidence of the use of revenues (Youngman, 2001). Majority of the locals believe that their money would go directly to individual pockets with not clear structure put in place. The challenge is as a result of unstable local government system, and according to Mbetu (1997), Mogadishu local government has not done much to ensure awareness is executed in every part of the capital to increase revenue collection.

Lack of taxable properties census and community centers: Mogadishu local government is in no position within the country's jurisdiction to carry out registration of all sources of commercial centers and taxable properties because of the failure of the difficulty from the government to conduct census (Local Government and 
Decentralization, 2009). The difficulty is as a result of security challenges faced, lack of enough funds considering the process is tedious and expensive. As a result, Mogadishu has numerous operational business centers that do not pay any taxes (Slootweg et al., 2007). For instance, the taxation department direction during my survey confide in me that he managed to only register 229 business centers in the entire Hamarjabjab district and a total of 40 centers only took business licenses.

Lack of municipal soldiers: Collection of taxes is a tedious and demanding task.

Survey conducted in Mogadishu revealed that there are few or no municipal soldiers at all to ensure those refusing to pay taxes are arrested and charged. Several factors contribute to this phenomenon (Slack, 2010). First, security in Mogadishu is a big problem, which has resulted in huge population of municipal soldiers killed. The extremist group has vast in the area prompting the remaining soldiers abandon their duties (Hyman, 1990). Additionally, lack of municipal soldiers is due to lack of enough finances to pay them, which is also because of limited collection of revenues.

The policy makers are mandated to come up with a plan on how to develop functioning revenue collection systems, but from the survey conduction on the local government, there is reluctance and contentment on the amount of revenue collected. The reason for their contentment is because the local government has not budget, which will offer direction that would cover their proposed budget. The study also shows that the local government spends total amount received from revenue collection, and according to Due \& Mikesell (1994), when the revenue becomes insufficient in meeting their needs, they; reduce the employees' salary, or decrease the employees' number, or they reduce or totally stops sanitation services, community support, and street lights.

Property taxes, user charges sales, and land sales taxes: Mogadishu local government does not collect its revenues from these sources like majority of other local governments. This is a challenge on the ability of the local government to self-finance its operations (Chernick et al., 2010). The above revenue sources inflict heavy burden on the ordinary citizens if executed because exorbitant fees are demanded. Again, lack of wellestablished property is another reason for lack of such exercise (Bordignon et al., 2001). Lack of or minimal revenue collection is also a challenge to payment of enough trained staff, and people usually feel this form of employment based on the Somali context. The lack of awareness also plays a role in sensitizing the locals on what the employment entails.

Finally, Mogadishu as the capital of Somalia, experience disputes between the central and local government in relation to collection of revenue. The disputes is related to lack of tax laws, which mentions the kind of taxes the local government is supposed to collect and the kind the central government handles (Banigana, 2007). Currently, there is a compromise through the use of socialist systems laws from the pre-civil wars.

\section{Conclusion and Recommendations}

Under the fiscal decentralization, less-developed countries like Somalia have since been presented with Revenue capacities. Reasons for this are as a result of relation to the challenges in collection of revenues from all spheres for Revenue. Mogadishu local government for instance has a range of challenges from security issues as the main challenge to lack of awareness and advanced revenue collection methods among others. Inability of the local government to self-finance is attributed to some of the interlocking factors (Slack,

2002). Such factors include inhospitable social contexts, unwelcoming environment, overreliance on minimal taxes collection, lack of enough tax generating ventures, and failure to develop optimizing revenue strategies.

The government of Somali should therefore come up with strategies and structures to solve security issues, which include seeking financial help from the developed countries to hire more security officers. Secondly, the local government should built sustainable markets, which will help contribute to increase in the amount of revenue collection (Slack, 2007). Since there is CIP in Mogadishu, the local government should therefore developmental projects, either large or small, with the aim of improving CIP to facilitate increase trust from the community; this way, the community will be willing to pay taxes to facilitate various projects (Schou, 2000). The local government should also sought out consultation and collaboration from the governmental levels and other actors to help strengthen the local finance systems for efficient collection of revenue. 


\section{References}

[1] Banigana, E. (2007). Somalia: Fiscal Policy Choices in a Post-Conflict Environment. Presented at the Fourth Annual CABRI, Seminar 6 December, 2007.

[2] Bird, R. M., \& Slack, E. (1993). Urban Public Finance in Canada. Toronto: John Wiley and Sons.

[3] Bordignon, M., Gianni, S., \& Panteghini, P. (2001). Reforming Business Taxation: Lessons from Italy? International Tax and Public Finance, 8, 191-210.

[4] Chernick, H., \& Reschovsky, A. (2006). Local Public Finance: Issues for Metropolitan Regions.

[5] Chernick, H., Langley, A., \& Reschovsky, A. (2010). Revenue Diversification and the Financing of Large American Central Cities. Working Paper, Lincoln Insitute of Land Policy, Cambridge, MA.

[6] Due, J. F., \& Mikesell, J. L. (1994). Sales Taxation, State and Local Structure and Administration. Washington, DC: Urban Institute Press.

[7] Fox, W. F., \& Gurley, T. (2006). Will consolidation improve sub-national governments? Washington, DC: World Bank.

[8] Hyman, D, N. (1990) Public Finance: A Contemporary Application of Theory to Policy. Fort Worth: Dryden Press.

[9] Kubler, D., \& Rochat, P. (2010). Governance and Finance of Large Metropolitan Areas in Federal Systems: Switzerland. Zurich.

[10] Local Government and Decentralization (2009) Fiscal Decentralization and Options for Donor harmonization (Berlin: Local Government and Decentralization)

[11] Magala, C. \& Rubagumya, A (2005). Why Pay? Motivators for Payments of Local Market Dues in Rwanda and Somalia. Amsterdam: SNV.

[12] Mbetu, M. R. (1997) Rural Development in Practice: The Process Approach, Capacity Building and Empowerment: Experiences from Somalia. Coventry: Coventry University Press.

[13] Mulindabingwi, V. \& Singer, U. (2005) Funding Local Government. Royal Tropical Institute. Amsterdam.

[14] Myers, D. and Dietz, H. (2002) Capital City Politics in Latin America: Democratization and Empowerment. Boulder Colorado: Lynne Rienner.

[15] Parker, S. (05 July 2010) Corruption and Governance Programme, Institute for Security studies, Cape Town

[16] Roy, K (1999) Designing a Property Tax Reform Strategy for Sub-Saharan Africa. Howard University: Howard

[17] Sano, H, O. and Alfredsson, G. (Eds) (2002) Human Resources and Good Governance: Building Bridges. The Hague: Nijhoff

[18] Schou, A. (2000) Democratic Local Government and Responsiveness: Lessons from Zimbabwe and Tanzania. International Journal of Comparative Sociology. XLI, I, 121-143.

[19] Slack, E. (2007). Managing the Coordination of Service Delivery in Metropolitan Cities: The Role of Metropolitan Governance. Washington, DC: The World Bank.

[20] Slack, E. (2002). Municipal Finance and the Pattern of Urban Growth. Toronto: C.D. Howe Institute.

[21] Slack, E. (2010). The Property Tax ... In Theory and Practice. Paper presented at the 6th Symposium on Fiscal Federalism, Barcelona.

[22] Slootweg, S, Groen, J and Llopart, X. (2007). What Makes Local Government Work? Social Capital, Leadership, Participation and Ownership in Benin. 
[23] Thirsk, W. (1982). Political Sensitivity vs. Economic Sensibility: A Tale of Two Proeprty In Thirsk, W. \& J. Whalley, (2009). Tax Policy Options in the 1980s (pp. 384407). Toronto: Canadian Tax Foundation.

[24] Weeks, A, Liam, H and Quinlivan, E. (2009) All Politics is Local. A Guide to Local Elections in Ireland. Cork Collins Press.

[25] Youngman, J. (2001) Development of Property Taxation in Economies in Transition: Case Studies from Central and Eastern Europe. Washington D.C.: World Bank. 